\title{
THE DEVELOPMENT OF ENTREPRENEURSHIP IN RURAL AREAS IN PODKARPACKIE PROVINCE
}

\author{
Bogusław Ślusarczyk, PhD, Associate Professor ${ }^{1 *} ;$ Karol Sołek, DEng ${ }^{2^{* *}}$
}

${ }^{1}$ Faculty of Economics, University of Rzeszów

${ }^{2}$ Accountancy Department, Institute of Agricultural Economics and Food Economy

${ }^{*}$ https://orcid.org/0000-0003-0567-8470

${ }^{* *}$ https://orcid.org/0000-0002-1675-2085

\begin{abstract}
The study is devoted to the diagnosis of entrepreneurship development in rural areas. The aim of the work is to analyse and evaluate the dynamics and directions of entrepreneurship development in rural areas of the Podkarpackie province as well as to identify changes and trends as well to present the strengths and weaknesses of rural areas in the studied area. On the basis of the conducted research, it can be concluded that the number of business entities in rural areas is systematically growing, and forecasts indicate further development. Assessment of directions and dynamics of entrepreneurship development based on the number of entities by selected NACE sections in 2009-2017 showed no significant variation in trends in all counties the trends are similar. The largest growth dynamics relate to communication and information services on, the real estate market as well as rental services for buildings, machines or devices, job market mediation, tourist services, detective or security services, maintenance of cleanliness and order, development of green areas, and office administration. In turn, industries such as agriculture, forestry, hunting and fishing, wholesale and retail trade, vehicle repairs, financial and insurance activities were characterized by a reverse tendency - a systematic decline in the number of business entities occurred. The remaining sections of PKD (Polish classification of activities) maintained a stable, unchanging level.
\end{abstract}

Key words: entrepreneurship, rural areas, enterprise, Podkarpackie province, development JEL code: L26

\section{INTRODUCTION}

Entrepreneurship in rural areas is an important factor and indicator of the economic development level (Kamińska, 2011). Individual economic activity is the driving force of the economy in rural areas (Kłodziński, 2010). It is also an important factor counteracting the unfavourable socio-economic proc- esses, such as unemployment, exclusion and marginalization. Economic activity of rural residents is also a prerequisite for economic success (Bański, 2008).

The rural economy has undergone significant changes over the past few decades. The share of agriculture in the production of gross value added is constantly decreasing, while the share of the services sector in the level of production is increasing. This

${ }^{1}$ Corresponding author: Ćwiklińskiej 2, 35-601 Rzeszów, Poland, boguslaw.slusarczyk@gmail.com, +48 509636066

${ }^{2}$ Corresponding author: Świętokrzyska 20,00-002 Warszawa, Poland, karolsolek@o2.pl, +48 887447008 
trend is observed in all EU Member States, especially in south European countries. However, demographic forecasts for the future of the European village are unfavourable.

Interest in the future and condition of rural areas in Poland is also dictated by the fact that, according to the methodology of their separation by the GUS (Statistics Poland), based on administrative division, they occupy over $93 \%$ of the country and are inhabited by approximately $38.8 \%$ of the total population (state on 2017). In the Podkarpackie province, in recent years, a strong emphasis has been placed on the development of rural areas, with a special attention paid to the development of entrepreneurship.

\section{MATERIALS AND METHODS}

The aim of this paper is to analyse and evaluate the dynamics and directions of entrepreneurship development in rural areas of the Podkarpackie province as well as to identify changes and trends and to present the strengths and weaknesses of rural areas in the studied area. The study covered rural communes and a part of urban-rural communes. The analysis was based on GUS (Statistics Poland) data contained in the Bank Danych Lokalnych (Local Data Bank). The method of comparative analysis based on secondary and primary data was used. In turn, inference for deduction based on the analysis of the subject literature and source documents was used to determine the expected future changes. The paper is a contribution to further research on the development of economic activity in this area.

\section{RESULTS AND DISCUSSION}

\section{Concept of multifunctional rural development}

One of the basic multi-functionality assumptions, and thus economic activation of a village, is the creation of jobs outside the agricultural sector and integration of agriculture with other branches of the rural economy, in which entrepreneurship is the most important. The above paradigm of rural development assumes the cooperation of their market, social and environmental functions.

Most economists and scientists confirm the view that entrepreneurship is becoming a key factor in the well-being of societies. However, the multifaceted nature of the term "entrepreneurship" implies that, despite the broad bibliography on the phenomenon of entrepreneurship, there is no single, universal definition of the concept. This is due to the fact that this process goes beyond the scope of economics, because it is located on the borderline of many other children of science, such as psychology, sociology, economic geography, etc. (Raczyk, 2009). As early as 1934, Schumpeter (1934) pointed out that "an entrepreneur is an innovator, who introduces an entrepreneurial change within markets, where entrepreneurial change has five symptoms: (1) introduction of a new/ /improved good; (2) introduction of a new production method; (3) opening of a new market; (4) use of a new source of supply; and (5) introducing a new organization in every industry".

An entrepreneur is therefore a person with a high need for achievement. This need is directly related to the entrepreneurship process. At the same time, the entrepreneur is a moderate risk taker, who accepts the possibility of failure. However, the owner of an economic entity recognizes and uses market opportunities (McClelland, 1976). Such a person is characterized above all by innovative behaviour and the ability to use strategic methods of business management (Shapero, 1975). Therefore, entrepreneurship is an attempt to create value by recognizing business opportunities (Kao and Stevenson, 1985). It is a way of thinking, reasoning and acting, taking advantage of opportunities, but with a holistic approach and balanced leadership (Timmons and Spinelli, 1999). The basis for the functioning of the modern concept of entrepreneurship is innovation (Kukoc and Regan, 2008).

A village is to become a place of production development and trade activities as well as provision of various services. The main factor for the development of multi-functionality is entrepreneurship and financing of infrastructure investments that improve the quality of life in rural areas, but also increase the investment attractiveness of the area. The concept of multifunctional rural development is to be a response to the problems of managing the rural space in regions that are particularly backward, critical and hard to reach. 
According to Bryden and Hart, entrepreneurship is the most important factor in the professional and social revitalization of rural areas. It makes it possible to avoid traps connected with mono-production, improves the quality of life of rural communities and increases the level of their integration. By improving the availability of services, negative phenomena associated with depopulation can be stopped and they can even attract potential new residents to these areas (Bryden and Hart, 2005)

An important task of rural policy is the selection of such instruments that will encourage rural residents to undertake economic activity. According to the research carried out by OECD, the level of entrepreneurship depends on the possibility of obtaining financing for business operations. According to the report, rural enterprises have very limited financing possibilities, and funds for the development of rural companies come mainly from own resources or loans granted by the entrepreneur's family or friends ( $\mathrm{Tu}$ dor and Voicilas, 2010).

The concept of multifunctional rural development, in addition to stimulating the local entrepreneurship, also assumes investments in infrastructure in rural areas. Its condition affects the conditions of running a business, the result of which depends on road connections with urban areas and the availability of information and communication technologies for rural enterprises. However, taking into account the demographic trends concerning the European village, the decrease in the number of inhabitants, and thus also the income of local self-governments, causes restrictions in the implementation of investment projects.

Multifunctional rural development is to be a process that takes place simultaneously on many levels. It includes spatial, social and economic changes that enable residents to obtain income from professional activity and improve the quality of life (Stanny, 2012).

\section{Development trends in the Podkarpackie province}

Development trends have been observed in the Podkarpackie province located in the south-eastern part of the country. Neighbouring regions are: Lviv in Ukraine and Košice in Slovakia along with the following Polish provinces: Lublin from the north-east,
Świętokrzyskie from the north-west and Małopolska from the west. It covers an area of $17846 \mathrm{~km} 2$, which is $5.7 \%$ of the country's area. Rural areas occupy about $94 \%$ of its territory.

The Podkarpackie province is characterized by specific features that include: low level of economic development with significant internal differentiation of its features, very high rural population $(58.6 \%)$ in the total population of the province and problems of rural development, economically poor agriculture with a high percentage of people living off work in agriculture and a small propensity to change this sector of the economy, border location (eastern and southern border of Poland) and resulting peripherality of the province, high share of legally protected areas in the overall area of the province, but poor use of natural resources for the development of prospective sectors of the economy (tourist and health services) (Czudec, 2007).

At the time of Poland's accession to the European Union, these areas proved to be the least developed in the country. Based on the Eurostat research from 2002, they were considered the regions with the lowest GDP per capita in the European Union (OP DEP 2007-2013). It was a determinant for development for those provinces with a similar level of GDP (Eastern Poland), a special supra-regional program supporting social and economic development - Operational Program Development of Eastern Poland 2007-2013 (OP DEP) and in the following years - Operational Program Eastern Poland 2014-2020 (POPW).

In 2015, according to the GUS (Statistics Poland), there were 4,184,409 business entities in Poland, of which $1,130,658$ registered in rural areas, which constituted over $27 \%$ of all entities. On the other hand, in the analysed area of economic enterprises in rural areas, 70683 were recorded in the Podkarpackie province and it was the largest percentage in the region of south-eastern Poland.

In the Podkarpackie province in 2018, there were 174.8 thousand business entities registered in the REGON (National Official Register of National Economy Entities) this is an increase of 3.8 thousand (2.2\% compared to 2017). Entities from the Podkarpackie province accounted for $4.0 \%$ of all entities registered in the national official register of the national economy entities REGON. 
The vast majority of entities (167.7 thousand), i.e. $95.9 \%$, belonged to the private sector, while public sector entities (5.3 thousand) accounted for $3.1 \%$. In comparison with 2017, private sector entities were by $2.1 \%$ more, and public by $0.3 \%$ less. The largest number of public sector entities carried out activities related to education $-47.1 \%$ in 2018 , then with real estate services $-16.1 \%$, public administration and national defence; compulsory social security $-11.7 \%$ as well as health care and social assistance $-9.1 \%$. Among the private sector entities, 77.4\% (129.9 thousand) were natural persons conducting business activity, mainly in the field of trade and repair of motor vehicles $-25.7 \%$, construction $-16.7 \%$, industrial processing $-10.2 \%$ and professional, scientific and technical activity $-10.1 \%$. Among the natural persons conducting business activity, 99.1\% were microenterprises, i.e. entities employing up to 9 persons. Among natural persons running business activity, there were 41.0 thousand women, which accounted for $32.7 \%$ of the total. In comparison with 2017 , there was an increase in the number of entities operated by women (by 631 ), i.e. by $1.6 \%$.

Most entities of the national economy were active in the sections (Fig. 1): trade; repair of motor vehicles -41.6 thousand $(23.8 \%$ of the total); then construction -24.1 thousand (13.8\%), industrial processing -
16.7 thousand (9.5\%) and professional, scientific and technical activity -15.6 thousand $(8.9 \%)$. Among the registered entities, there were definitely predominant ones that declared predicted employment no more than 9 people; they constituted $95.7 \%$ of all registered units. The share of small entities (with the expected number of employees from 10 to 49 people) was $3.5 \%$, medium-sized entities (from 50 to 249 employees) $-0.7 \%$, and large (250 employees and more) $-0.1 \%$ (Statistics Poland, 2019).

Entities of the national economy in terms of population and area in 2017 in the Podkarpackie province per 1,000 population accounted for 80 entities of the national economy (79 before), while 112 in the country of (110 before that year). The largest number of entities per 1,000 population was registered in cities with county rights: Rzeszów (146), Krosno (122), Przemyśl (105) and Tarnobrzeg (103) and in the Lesko county (113), and the least in the counties: Przemyśl (58), Brzozów and Lubaczów (after 59) and Przeworsk (60) - Figure 2.

In 2002, the number of companies in the Podkarpackie province amounted to over 56 thousand, in 2015 there were around 71 thousand of them. When analysing the dynamics of changes in the number of business entities in the rural areas of Poland in the analysed province, an increasing trend can be observed.

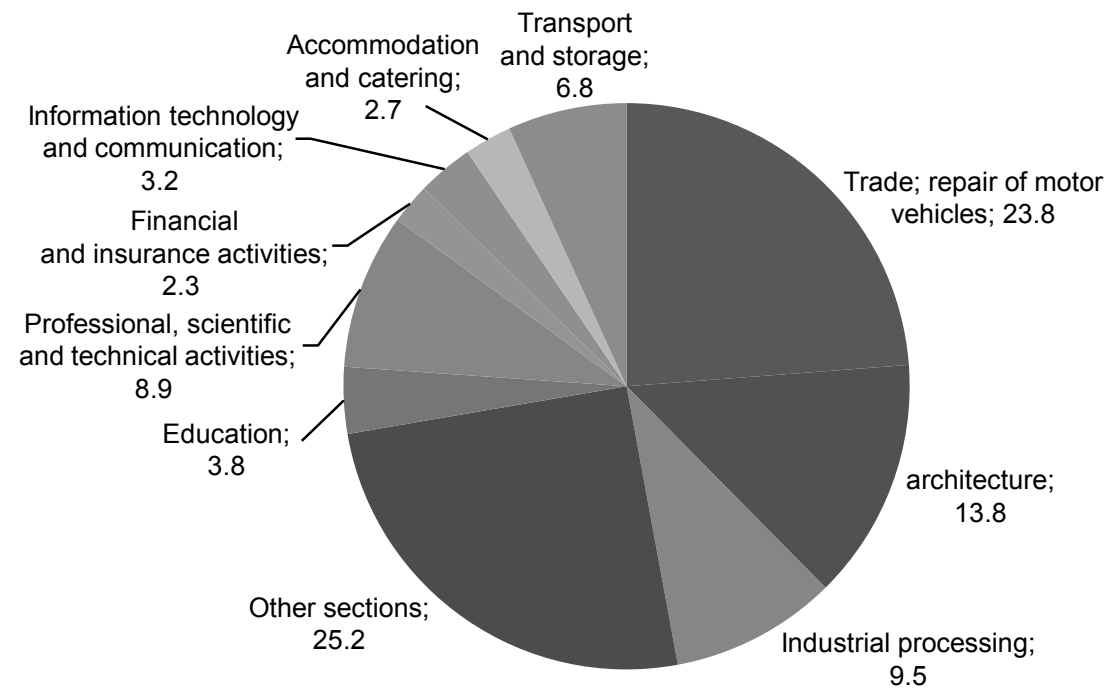

Figure 1. Structure by type of activity and expected number of employees

Source: own study based on data from Local Data Bank (Statistics Poland, 2018). 

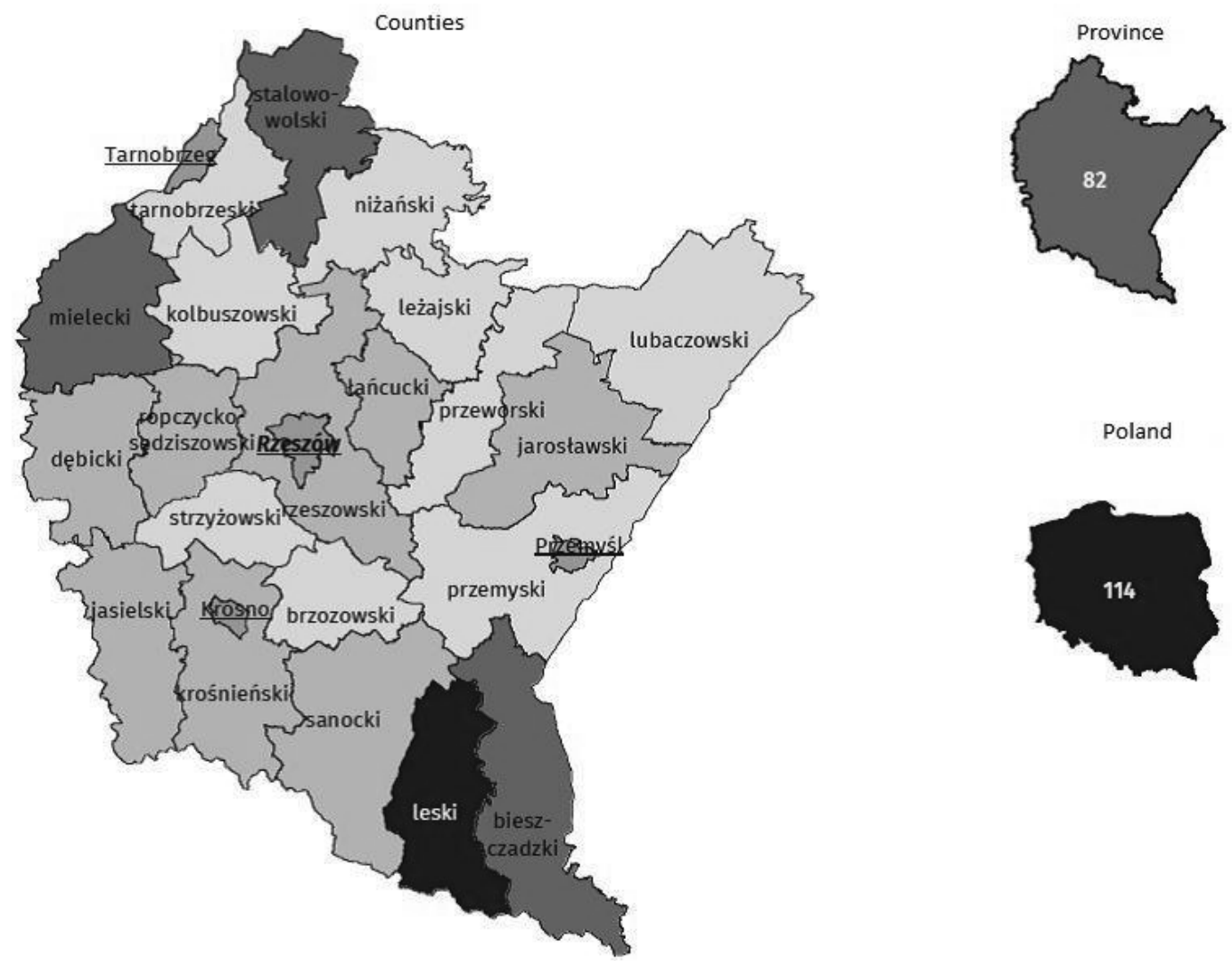

Figure 2. Entities of the national economy per 1,000 population by poviats in 2018

Source: Entities of the national economy in the REGON in the Podkarpackie province, Voivodship Labour Office in Rzeszów (2019).

The development of non-agricultural functions of rural areas should be correlated with the nature of resources and endogenous potential of a given rural area. Therefore, the implementation of the rural development policy should be bottom-up, as decentralized as possible, and the programs and priorities of measures must be compatible with the resources available to the regions. The territorial approach, taking into account the specificity of a given rural area, and the diagnosis of development problems can help solve these problems. Possible variants of rural development depend on the following factors (Kłodziński and Rosne, 1995):

- natural (geographic location, terrain, climate, natural resources);

- demographic (age and social structure of rural population, migration balance, rate of natural increase);
- economic (structure of the rural economy, ownership relations, employment structure, state of human capital);

- infrastructure (state of technical, social and institutional infrastructure);

- socio-cultural (identity, values, norms, level of entrepreneurship).

From a broader perspective, entrepreneurship refers to the individual's ethos, based on standards, values and motivations, which results in undertaking the activity (Michalewska-Pawlak, 2012). Entrepreneurship is therefore equated with initiative, resourcefulness as features of the human personality, which contribute not only to his personal success, but also to broadly understood local development. Entrepreneurship is therefore not only about individuals running their own businesses and is not limited to the business sector, but also includes the attitudes and behaviours 
of all residents of rural areas in matters that directly affect them. The level of activity refers to the owners of companies, farmers, local authorities, and leaders of social organizations responsible for the economic and social processes taking place in these areas.

The implementation of regional policy is implemented by two structural funds: the European Regional Development Fund (ERDF) and the European Social Fund (ESF). According to the program assumptions concerning regions, they are convergent with the assumptions of national programs, and their priorities include tasks in the areas of: innovation, scientific research, information and communication technologies, enterprises' competitiveness, low-emission economy, infrastructure development, rail and road connections, and also investments in environmental protection and energy.

The Podkarpackie province is characterized by the lowest saturation with economic entities from the REGON for 10,000 inhabitants, although comparable with rates from other provinces from the eastern part of the country - Lublin and Podlasie. In addition, small family enterprises with low sales and low competitiveness and innovation prevail in the structure of business entities. Small and medium-sized enterprises have still not fully used development potential. The share of the SME sector in sales revenues is smaller than its share in the total number of employees, which indicates lower productivity of this sector. The unemployment rate in the Podkarpackie province in 2016 was $11.6 \%$ and it was one of the highest rates in the country. The highest unemployment rate was recorded in the following counties: Nisko, Lesko,
Bieszczady, Strzyżów, Przemyśl and Brzozów. These are the areas constituting the inner regional development peripheries (Strzyżów, Brzozów) or outer peripheries located near the border with Ukraine (the belt of counties in the eastern part).

It is believed that the support for entrepreneurship and competitiveness of enterprises in the non-agricultural sector will be crucial in the future financial perspective. Road and technical investments as well as increasing the accessibility of these areas to capital investments should become a priority in the subsequent period. Owners of enterprises in rural areas very often face difficulties that are rare in urban agglomerations. Additional obstacles for rural entrepreneurs is the small size of local markets, as well as limited access to necessary services such as financial services, information and advice. Other issues include the lack of facilities designed to run business, less developed transport and telecommunication infrastructure, as well as limited networking and cooperation opportunities. In order to assess the directions and dynamics of entrepreneurship development, the number of entities according to selected PKD (Polish classification of activities) sections in 2009-2017. In all provinces of Eastern Poland, trends were similar. Almost in every sector of the national economy, an upward trend can be observed in the studied region. The most dynamic growth characterized Section I - communication and information, Section L - activities related to real estate market services; Section $\mathrm{N}$ - activities in the field of administration services and business support activities such as rental and lease services for buildings, buildings, machinery or equip-

Table 1. Strengths and weaknesses of the rural areas of the Podkarpackie province

\begin{tabular}{|l|l|}
\hline \multicolumn{1}{|c|}{ Strengths } & \multicolumn{1}{c|}{ Weaknesses } \\
\hline One of the highest rates of natural increase & Low level of basic infrastructure \\
\hline $\begin{array}{l}\text { A large number of potential employees live a short distance } \\
\text { from the main development centres of the region }\end{array}$ & Low entrepreneurship \\
\hline \multirow{4}{*}{ The highest social activity index in the country } & High unemployment rate \\
\cline { 2 - 3 } & Low level of remuneration \\
\cline { 2 - 3 } & A small share of employees in services \\
\cline { 2 - 3 } & Agrarian fragmentation and low commodity of agriculture \\
\hline
\end{tabular}

Source: own study. 
ment, job market mediation, tourist services, detective or security services, maintenance of cleanliness and order, development of green areas, administration office, etc. In turn, in such departments as Section A - agriculture, forestry, hunting and fishing; Section G - wholesale and retail trade; repair of motor vehicles, including motorcycles; Section $\mathrm{K}$ - financial and insurance, the activity can be seen as subjected to the opposite tendency - a systematic decrease in the number of business entities.

The intelligentsia specializing in rural areas of the province should concentrate on their tourist functions. It should be expected that the development of organic farming in the Podkarpackie province will result not only in the absorption of excess labour in agriculture, but also the emergence of small enterprises processing organic raw materials and tourist facilities offering local, traditional and low-processed food.

The analysis shows that the Podkarpackie province is developing unevenly, and this development is very diverse in individual municipalities. The largest social development takes place in the central and north-western region of the Podkarpackie province. It consists of many factors, but the most important ones are those that have a well-developed communication network: the A-4 motorway, the Jasionka airport, the migration balance and the influx of new companies in these regions are of great importance here.

\section{SUMMARY}

The Podkarpackie province is growing. However, this development is slow, especially when compared to other regions. The reason for the low level of the region's economic development can be seen as its low investment attractiveness. The province has poorly developed transport and communication infrastructure. A significant part of the region is rural areas with an economy based on agriculture, which, despite of having to invest using the EU funds, still needs modernization. Entrepreneurship is characterized by great fragmentation, and investing in improving innovation and competitiveness of companies requires large financial capital, which small companies do not have and which are difficult to obtain.
Based on the above analysis, it can already be stated that the specificity of the region, its level of development and unfavourable processes occurring within it (increasing the distance to other regions) indicate that this region should be considered difficult, requiring continuous development, inflow of capital and growth of entrepreneurship. The problem of economic activity in rural areas of the Podkarpackie province is similar in all provinces of eastern Poland and does not significantly polarize. In less developed communes, entrepreneurship can be a very important factor in activating the population and improving the living standards. This phenomenon has the effect of reducing the disproportion in the income level of individual social strata and at the same time, it contributes to the mitigation of unemployment-related phenomena. The increase in demand is also an increase in interest in rural areas in order to invest and locate business ventures. On the basis of the conducted research, it can be concluded that the number of business entities in rural areas of the Podkarpackie province is systematically growing, and the forecasts indicate further development of entrepreneurship. The purpose of implementing measures in this area is to increase the level of entrepreneurship and improve the region's competitiveness. Thus, the funds are mainly addressed to business entities implementing projects in the field of research and development and introducing the innovative solutions. The expected result of this type of activities will be to strengthen the cooperation between the R\&D sphere and to achieve the objectives set within the framework of ongoing aid programs.

On the other hand, the assessment of directions and dynamics of entrepreneurship development on the basis of the number of entities by selected NACE sections in 2009-2017 showed no significant variation in trends within the study area. The greatest dynamics of growth characterizes services related to communication and information, real estate market service and rental and lease services of buildings, buildings, machines or devices, job market mediation, tourist services, detective and security services, maintenance of cleanliness and order, development of green areas, administration office. In turn, industries such as agriculture, forestry, hunting and 
fishing, wholesale and retail trade, vehicle repairs, financial and insurance activities were characterized by a reverse tendency - a systematic decrease in the number of business entities. The remaining sections of PKD maintained a stable, unchanging level. The financial perspective covering the years 2014-2020 is currently being implemented, therefore it is extremely important for the region to use the financial resources that can be obtained under EU development policy rationally. It is anticipated that it will be the last period of Poland's use of such significant external funds, decisive for the dynamics of socioeconomic development of both the country and the Podkarpackie province. However, the financial situation of entities, especially local government units, may be an obstacle in their acquisition.

\section{REFERENCES}

1. Bański, J. (2008). Wiejskie obszary sukcesu gospodarczego. Przegląd Geograficzny, 80, 2, pp. 199-222.

2. Bryden, J., Hart, K. (2005). Why local economies differ: the dynamics of rural areas in Europe. The Edwin Mellen Press, Aberdeen.

3. Czudec, A. (2007). Ekspertyza dotycząca województwa podkarpackiego. In: Ekspertyzy do Strategii Rozwoju Społeczno-Gospodarczego Polski Wschodniej do roku 2020. Vol. Ministerstwo Rozwoju Regionalnego, Warszawa, s. 231-254.

4. Directive 2008/98/EC of the European Parliament and of the Council of 19 November 2008 on waste and repealing certain Directives. OJ L 312 of 22.11.2008.

5. Eurostat (online data code: env_wasgen). Retrieved: http://ec.europa.eu/eurostat/statisticsexplained/index. $\mathrm{php} /$ Waste_statistics [Access 05.01.2017].

6. GUS [Statistics Poland] (2013). Ochrona środowiska 2012 [Environment 2012]. Warszawa.

7. Janka, W. (2015). Historia gospodarki odpadami [History of waste management]. Zakład Gospodarki Komunalnej, Zielona Góra. Retrieved from: http://www.zgkim.zgora.pl/cms/images/pdf_files/C20_Historia_gospodarki_odpadami.pdf [Access: 09.01.2017].

8. Kao, J.J., Stevenson, H.H. (1985). Entrepreneurship, what it is and how to teach it: a collection of working papers based on a colloquium held at Harvard Business School. The School, Michigan.

9. Kłodziński, M. (2010). Mikroprzedsiębiorczość na obszarach wiejskich. Wieś i Rolnictwo, 2, (147), pp. 20-34 .
10. Kłodziński, M., Rosner, A. (1995). Wielofunkcyjny rozwój terenów wiejskich a polityka regionalna [Multifunctional rural development and regional policy]. In: K. Duczkowska-Małysz, M. Kłodziński, C. Siekierski (eds.) Polityka regionalna w rozwoju obszarów wiejskich. Wydawnictwo SGGW, Warszawa, p. 117.

11. Kukoc, K., Regan, D. (2008). Measuring entrepreneurship. Economic Roundup. Summer 2008. Australian Treasury, pp. 15-26.

12. McClelland, D.C. (1976). The Achieving Society: With a New Introduction. Irvington Publishers. Business \& Economics.

13. Michalewska-Pawlak, M. (2012). Social and cultural determinants of entrepreneurship development in rural areas in Poland. Research on Enterprise in Modern Economy - Theory and Practice, 1, pp. 51-65.

14. Program Operacyjny Rozwój Polski Wschodniej 2007 -2013. Narodowe Strategiczne Ramy Odniesienia 2007-2013 [Operational Programme Development of Eastern Poland 2007-2013. National Strategic Reference Framework 2007-2013].

15. Raczyk, A. (2009). Metody badania przedsiębiorczości oparte na rejestrze podmiotów gospodarki narodowej [Methods for Examining Entrepreneurship on the Basis of the Register of Units of the National Economy]. Przedsiębiorczość - Edukacja, 5, pp. 133-146.

16. Schumpeter, J.A. (1960). Teoria rozwoju gospodarczego [Theory of economic development]. PWN, Warszawa.

17. Shapero, A. (1975). The displaced, uncomfortable entrepreneur. Psychology Today, 9 (6), pp. 83-88.

18. Stanny, M. (2012). Społeczno-ekonomiczne zróżnicowanie obszarów wiejskich [Socio-economic diversity of rural areas]. In: Raport o Stanie wsi. Polska wieś 2012. Wydawnictwo Naukowe Scholar, Warszawa, p. 150 .

19. Timmons, J.A., Spinelli, S. (1999). New venture creation: Entrepreneurship for the 21st century. 5th edn. Irwin McGraw-Hill, New York.

20. Tudor, M., Voicilas, D.M. (2010). Innovation and real labour force in rural areas as a basis of future rural development. In: A. Fieldsend (ed.) Linking competitiveness with equity and sustainability: new Ideas for the socio-economic development of rural areas. University of Debrecen, Warsaw, p. 69.

21. Wojewódzki Urząd Pracy w Rzeszowie [Voivodship Labour Office in Rzeszów]. Sytuacja na rynku pracy [Situation on the labour market]. Retrieved from: http://wuprzeszow.praca.gov.pl/rynek-pracy/ statystyki-i-analizy/sytuacja-na-rynku-pracy [Access 21.04.2019]. 